\title{
Special Economic Zones as Growth and Anti-growth Poles as Exemplified by Polish Regions
}

\author{
Hanna Godlewska-Majkowska, Agnieszka Komor, Magdalena Typa
}

\section{A B S T R A C T}

Objective: The objective of this paper is to present the effects of special economic zones (SEZ) on the polarisation of public economic space in Polish regions.

Research Design \& Methods: The paper looks at both positive and negative effects of economic zones on the polarization of economic space in Polish regions. In an empirical analysis of internal and external effects of SEZs growth centres are identified. Centre of the polarised region, as a source of development incentives, characterised with a higher growth dynamics in comparison to the other part of the region is identified as a growth pole; while the centre of a polarised region being a source of crisis factors higher than in the region is identified as an anti-growth pole.

Findings: In the result of conducted studies 8 growth poles, 19 centres of unstable economic situation have been identified, anti-growth poles has not been identified. Factors that result in the polarisation as well as its positive and negative characteristics were identified.

Implications \& Recommendations: The new model, which captures growing changes and can activate an appropriate action aimed at avoiding crisis can be used as a potential early warning system by the authorities of territorial units.

Contribution \& Value Added: The originality of this work lies in proposing a new methodological approach to identify poles and anti-poles. This approach can be applied for various tiers of taxonomic division for regions in various countries and forms of public aid.

\begin{tabular}{|c|c|}
\hline Article type: & research paper \\
\hline ds: & $\begin{array}{l}\text { anti-growth poles; investment attractiveness; growth poles; public } \\
\text { aid; special economic zones (SEZ) }\end{array}$ \\
\hline $\mathbf{L}$ & L52, R53, R12, P48 \\
\hline
\end{tabular}

\section{Suggested citation:}

Godlewska-Majkowska, H., Komor, A., \& Typa, M. (2016). Special Economic Zones as Growth and Anti-growth Poles as Exemplified by Polish Regions. Entrepreneurial Business and Economics Review, 4(4), 189-212, DOI: http://dx.doi.org/10.15678/EBER.2016.040412 


\section{INTRODUCTION}

Special economic zones (SEZs) are considered one of the most successful measures in regional policy that are applied to overcome barriers to regional development. One should consider not only a positive scenario in which the special economic zones become growth poles, but also think about the opposite course of actions. It is possible that the zones generate adverse effects, which not only fail to create growth generators, but may even hamper the growth or cause a spate of negative phenomena that intensify one another (i.e. negative synergy).

A negative scenario is probable when state aid is not adjusted in terms of its scale, kind or form to the characteristics of a given region/locality and investments in the zones. This causes overexploitation/misappropriation of resources instead of stimulating development in a viable manner. Therefore it is important to identify mechanisms which either cause the positive scenario to happen, in which case a growth pole is created by the special economic zones, or activate the negative scenario productive, which involves the creation of an "anti-growth pole".

For the purpose of this study, we decided to use the term growth pole in a reference to a centre of a polarised region, which is the source of growth incentives and is characterised by a higher growth dynamics in comparison to other parts of the region. Antigrowth pole is a polarised region's centre, which is a source of the crisis signals higher than the rest of the region. Region can be considered as a group of spatial units on different levels of taxonomic division (e.g. local, mezoregional, macroregional).

The role of poles or anti-poles can be played by not only single entities, but whole groups of them, or by development strategies of large enterprises (especially corporations), as well as by economic incentives systems, which can cause spatial structure modifications created by large enterprises. Special economic zones can have a special role in this.

The goal of this paper is to demonstrate both positive and negative effects of economic zones on the polarization of economic space as exemplified by Polish regions. Conclusions presented in this paper will help to identify the factors that either increase the chances of the positive effects contributing to the development of the economic zones or cause their negative effects to prevail.

The proposed research methodology aims at delimiting poles and anti-poles on the level of municipalities that have SEZs within their borders. Delimitation procedure was conducted on the basis of internal and external activities of the SEZ in the municipality. The evaluation of internal effects was based on direct effects of enterprises located in these zones, while the external effects evaluation was a result of assessment of multiplier effects of a supply and income character. The paper proposes a procedure and a research tool developed for monitoring the changes that occur because of the polarisation of the region. This model can serve as the basis of an early warning system which could potentially be used by the authorities of territorial units.

The results of the analysis may be applied not only to foster the development of Poland's regions, but also the regions located in other countries, based not only on SEZ, and also on other forms of public aid, as the mechanisms of polarisation are universal in character. Consequently, they may be particularly useful to stimulate regional economy 
in underdeveloped agricultural regions and problem regions characterized by an anachronistic structure of regional economy based on industrial monoculture. Polish regions demonstrate a broad diversity and different capacities to absorb state aid, because polarisation mechanisms are universal.

The first part of the paper presents a literature review on the growth poles theories, development polarisation with a special attention to their positive and negative impact on development of other units. Furthermore, we presented considerations on the influence of special economic zones - as a kind of public aid - on the economic development with an emphasis on multiplier effect of a supply and income character. The conducted literature studies suggest that majority of studies concentrate on positive effects of SEZ that stimulate economic development on the different spatial scales. Literature lacks research analysing factors influencing the negative effects of this kind of public aid. It is a cognitive gap that we try to fill with this paper.

The next part of the article identifies Polish municipalities that are a subject of this research and have special economic zones within their borders. As a next step we have proposed a research method aimed at finding poles anti-poles of growth. Boundary conditions have been specified, which should be met by municipalities in order to become positive or negative centres towards nearby areas. Measures of the assessment of the internal and external effects (being the reflection of supply and income effects) have been described. Poles and anti-poles delimitation criteria have been identified depending on the measures describing external effects.

In the course of the studies 8 growth poles, 19 centres of an unstable economic situation have been identified and anti-poles have not been identified. Next, we have conducted the econometric analysis of polarization types in municipalities dependency from municipalities investment attractiveness, which have zones located within their borders. Also the results of the supplementary qualitative research with the use of an in-depth interview with the directors of five special economic zones in Poland were presented. It can be noted that qualitative studies confirmed the existence of poles in indicated places and lack of anti-poles in the studied period.

The last part of the paper presents the results of conducted analyses. During the research the most important factors of SEZs positive and negative influence on local and regional development polarization were identified. It needs to be stated that numerous threats connected with the creation of SEZs and the creation on anti-growth poles require to use the monitoring system of changes present in local and regional economy. Our model allows grasping the intensifying changes and preparing the prevention measures. The proposed method has a universal character and allows the assessment of a variety of public aid forms on the region's or country's economy no matter the given country's socio-economic starting point. It also fills the cognitive gap on the public aid's influence assessment on the municipality's economic growth.

\section{LITERATURE REVIEW}

The concept of the growth pole (fr. pôle de croissance) was introduced to the literature by Perroux (1955) as a phenomenon that surpasses the average level, and not one of extremes. The proposed conception of sectoral polarisation identifies the pole with the company, which is a driving force and exhibits a strong market position, rapid growth of 
economic activity and a number of network cooperation (Perroux, 1955). In the course of its evolution, the theory of growth poles has provided a spatial dimension. Myrdal (1957) and Hirschman (1958) are considered the creators of the regional version of the growth pole theory.

Significant contribution to the development of the concept of growth pole in terms of a geographical viewpoint was also introduced by Boudeville (1972) and Paelinck (1965). Among the new theoretical concepts relating to the theory of polarized development, a new concept of endogenous growth and the concept of a new economic geography may be distinguished. According to Churski (2011), the latter concept is actually a new theory of polarised development.

In the literature, the term pole may theoretically determine both positive and negative effects of the impact of the growth of one unit on the development of other units. According to Perroux (1955), these are stimulating, inductive (fr. effets d'entraînement) or inhibitory effects (fr. effets de stoppage). Hirschman (1958) explains poles as opposite endpoints of one axis, wherein the positive effects are described as trickling-down effects, while the negative effects are presented as the polarisation effects. Myrdal (1957) described progressive effects as spread effects, and regressive ones as backwash effects.

In the theory of growth poles less attention is paid to a negative scenario of polarization effect. However, in accordance with the principle of circular cumulative causation by Myrdral (1957), positive changes cause the cumulative growth process, while negative changes - a cumulative shortening process. It is the result of feedbacks increasing intensity of mutual influences of both positive and negative character, being one of the reasons that boost inequalities between growth centres and regions and other areas.

The role of a growth pole can vary over time. The natural ebb and flow of the system may cause the existing poles to become centres of stagnation. Maturation of growth poles and their gradual replacement by others is a natural and necessary process in the national economy, but may cause the collapse of the process of economic development for some local areas. Diversification and supporting the development of service activities may to some extent mitigate the negative effects of the changes (Mckee, 1987).

Shanzi and Feser (2010) studied the occurrence of spread-backwash effects on a part of the territory of China. They analysed the impact of economic growth in bigger cities on the support or inhibition of growth in smaller cities and counties and the geographic scope of the occurrence of spread-backwash effects. Their empirical study has generated mixed evidence of the spread effects of large cities growth. It should be noted that the growth poles in large cities could generate both positive and negative regional growth spillovers.

Parr (1999a) analysed the concept of growth poles in the context of regional economic planning. However, at the same time, it should be noted that the growth pole strategy may be recommended with regard to various regional problems, such as depressed-area revival, the encouragement of regional deconcentration, the modification of a national urban system and the pursuit of interregional balance. Among the characteristics of the strategy, the author mentioned the following: encourages employment growth and population growth in certain areas of the region, changes the spatial structure of employment and population growth within a region, identifies limited number of places that are potential growth poles and allows spatial discrimination or selectivity 
between locations. Spatial configuration of the planned poles, economic activity at the poles, external effects of the poles and the presence of a pole within an existing urban system (Parr, 1999a; 1999b) are all important for the implementation of the strategy.

Followers of the concept of polarised development emphasise that in reality, growth poles can develop independent of the surrounding peripheries, which challenges the theories of sustainable development. Nowadays, growth poles are described as a network connection system, which may be characterised by greater intensity than associations with the nearest geographical environment and companies from the periphery (Gorzelak \& Jałowiecki, 2000; Gancarczyk \& Gancarczyk, 2002). Then, the effect of growth pole on economic space may be marginalised or limited only to the negative effects that are described as exploration of endogenous resources of the region.

Large enterprises play a special role in the concept of Perroux (1955). They are treated as leading units creating growth poles. Classical approach to the leading units in accordance with growth poles theory in a global economy needs a modification due to changes in enterprises, as well as in the environment. Today an important role can be played by groups of enterprises (especially by those who cooperate with each other and share their knowledge), as well as development strategies of great enterprises (especially corporations) and by the economic incentives system which can cause the modification of spatial structures created by large enterprises. Special economic zones can have a special role to play, as well as ownership connections and supply chains caused by quality reasons and safety reasons.

Economic zones in terms of the economy are an instrument of economic policy for the development of the whole country, which it does by supporting certain regions or sectors. On the other hand, from the perspective of economic geography, it is an element of economic space capable of creating new spatial structures and developing location advantages. In physical terms, these are geographically separate places doing business on preferential terms. Zones are oriented to attract new investors. Relationships that business entities create with the environment are one of the main factors of economic development of the region. The level of investment in the enterprise decides about its influence on the spatial structure of the regional arrangements, leading to the perpetuation or transformation of the spatial structures of the region.

Few studies concern SEZs as growth poles. Most authors note that SEZs are created in order to accelerate regional development and focus on the functioning of the areas with economic advantages. As such, the impact mechanism of this instrument is rarely present in the literature.

Considerations on the SEZs impact on the economy can be found in literature. Kryńska (2000) notices that the idea of creating special economic zones in Poland in its first assumptions, was supposed to support economic development of problematic areas through attracting large industrial enterprises. According to Ofiarska (2000) SEZs were intended to complement Poland's industrial policy within the progress of selected industries, increase of domestic services and products' competitiveness, modern technologies and support of production for exports. On the other hand Fierla (2000) and Brdulak (2003) stress out that SEZs were supposed to limit the negative effects which accompany the transformation process, such as unemployment increase and rising differences in the development level of particular Polish regions. The SEZs importance as an instrument of 
counteracting marginalisation of the least economically developed regions was also noticed by Nazarczuk and Kisiel (2013), who implies that SEZs goals include, apart from new jobs creation in the underdeveloped regions, boosting economic development through the improvement of selected sectors, production structure diversification and local economy reconstruction.

Some of the authors emphesize the macroeconomic dimension of SEZs activity. Miłaszewicz (2011) spotted the SEZs role in the country's economic modernization through the influence on the increase of capital expenditure. On the other hand, Pastusiak (2011) perceives SEZs as an active investment policy tool, which aim is to attract foreign investors and economy's activation and in a result unemployment decrease and inflow of new technologies. Pilarska (2009) has a similar understanding. She describes SEZs as state's economic policy tool for decreasing unemployment, increasing underdeveloped regions' investment attractiveness and attracting foreign investors. Laskowski (2009) also points to the regional aspect of zones' functioning and identifies them as an instrument for fighting the inconvenient effects of public-economic transformation through bringing foreign investors to the areas in a danger of poverty and the use of existing technical and technological solutions, as well as smart management of unused industrial assets.

Usually the roles and goals of SEZs manifest themselves on the macroeconomic and regional levels. But some of the researchers point to its local character. Jarczewski (2007), Lizińska, Marks-Bielska and Kisiel (2011) perceive the SEZs role in the investment attractiveness of municipalities. Krzemiński (2009) underlines the SEZs' role in the spurring of local entrepreneurship in the underdeveloped, or affected with high unemployment, regions. Przybyła (2010) links the existence of zones with transformations in the city's functional structure especially connected with city's exogenous functions, thereby stressing the SEZs influence on the cities' economic base changes. In turn Ambroziak (2009) notices that zones became the tools of state's impact on the actions of economic entities, tools for economic growth stimulation of specific regions and for attracting foreign investments.

There are number of studies that examine how special economic zones contribute to the stimulation of regional development, but not in the perspective of the growth pole. Advocates of special economic zones as national or regional development strategies argue that the zones offer various benefits. At the national level direct benefits include foreign investments, job creation and export promotion, whereas indirect benefits involve transfer of technology and know-how, as well as facilitation of institutional liberalisation. At a local level the benefits for human resources entail increase in income and acquisition of professional skills, often described as the 'spillover effects.' Authors focus mostly on success stories of SEZs (Wong \& Chu, 1984; Moura \& Forte, 2010; Osinubi \& Amaghionyeodiwe, 2010; Brautigam \& Xiaoyang, 2011; Zeng, 2011; Saqib, Masnoon \& Rafique, 2013) and indicate the causes being the joint presence of various institutional and legal instruments, which range from tax havens to some combinations of areas with economic advantages and forms of support for the transfer of technology and know-how like science and technology parks or centres for entrepreneurship.

Examples of clusters that are created as a result of cooperation between SEZs and companies operating in the zones are widespread (Zhao, Chan \& Chan, 2012; Hsu, Lai 
\& Lin, 2013). Researchers also describe eco-parks, which may offer attractive conditions for the growth of companies that develop green innovations (Shi, Chertow \& Song, 2010), or apply corporate social responsibility (Lai, 2006; Shen, 2007), or shared social responsibility (Christensen \& van Bever, 2014).

The literature is prevailingly descriptive and indicates the role of SEZs in regional development. However, studies on the mechanism of impact of SEZs on the economy and the universality of this impact are rare. Typa (2012; Typa, 2013a; Typa, 2013b) is one of the few scholars who describe special economic zones as growth poles. In her studies growth poles are presented through investigating the dynamics of development of municipalities (gminy), where SEZs are located, in comparison with one-tier higher taxonomic areas (LAU2). Typa's (2012) research leads to a conclusion that communes in the SEZs only develop into a growth pole if they are characterised by high investment attractiveness. They are mostly located in national and international transport corridors, densely populated regions with historically industrial background, which bear many features of problematic regions (prevalence of heavy industry, significant negative externalities, exceeding economies of scale). Studies also show heavy influence of SEZs location on the manufacturers of means of transport that are in a position of creating numerous cooperation ties. The municipalities in which SEZs, clusters and business environment institutions generated a synergy effect were the most successful. This author, however, only concentrated on positive aspects of space polarization.

Some authors also criticise SEZs. They believe the SEZs produce worse effects than complete economic liberalisation (Farole, 2011). The results of analysis of the role of SEZs in the liberalisation of the economies of China and India allow us to conclude that export and an increase in FDI have a positive statistically significant impact on the economic growth in those countries. The presence of SEZs increases the pace of regional development, but an increased number of SEZs have a scarce effect on economic growth. Increased pace of liberalisation seems to be the key to expedited economic growth. SEZs have also been investigated as liberalisation and development strategy vehicle for the economies of China and India (Leong, 2013). It should be noted that the creation of further subzones within the SEZs may potentially cause a dispersion of investments and a reduction in their desirable effects in addition to 'subzone cannibalisation,' i.e. rivalry between the subzones within one SEZ (Hajduga, 2011).

Broszkiewicz (2011) has reported on the disadvantages in the functioning of SEZs, which appear as a result of the influence of different factors characterised by legal and economic fluctuations. According to him, the possibility of doing business in the zone is strictly dependent on the current laws and changes in that area, as well as on global factors, e.g. economic crisis. The author also mentions that SEZs in Poland did not fulfil the purpose of their formation, which was the equalisation of disparities in the region.

Other authors highlight the needs of sectors that should be developed complementary to one another, and question their restricted learning faculty, their capacity for a technological spillover, or they argue that in fact SEZs intensify the discrepancy in the region's income (Park, 2005). However, it is difficult to generalise the effects of SEZs, as an overall research result is normally contingent upon a specific situation. According to Sigler (2014), the SEZs may in fact worsen the disparities in social development by creating entry barriers for a majority/part of a society (both physical and social restraints); 
allowing the import of a highly skilled workforce (instead of developing local training schemes); diminishing the benefits of international investments through a tax system that provides excessive tax reliefs; and allowing public authorities to be passive in implementing social development means and measures. For example, despite Panama's recent economic success many of its regions have been neglected by social services schemes, e.g. state-funded education or public healthcare. In the SEZ-supported sectors, entry barriers are high both in terms of required skills or know-how/qualifications and necessary capital outlays, whereas most positions with high or mean remuneration are occupied by national elite or well-educated expats. SEZs consequently contribute to the overall development of a national economy. If they are, however, intended to serve as a local development generator, broad complementary social development schemes need to be implemented to maximise social benefits of economic growth (Sigler, 2014).

It should be noted, though, that companies are not isolated but settled in certain locations and socioeconomic contexts that are also shaped by political and institutional players (Tödtling, Asheim \& Boschma, 2013). Although such zones turned out to be successful in the Dominican Republic, critics of the idea of creating various areas of economic advantages (here: export processing zones) underline the unfavourable lack of links and relations between companies located in the zone and firms outside it. This results in economic enclaves. According to the researchers, Export Processing Zones are not an optimum industrial development generator. They argue that it would be more beneficial to support export in the entire national economy because that generates network effects and adds higher value, which in turn contributes to an increased local employment rate, income and transfer of technology (Willmore, 1995). A study on another kind of economic enclave, Special Economic Zone of the Kaliningrad Oblast in Russia (Russian region surrounded by UE states, Lithuania and Poland), was presented in a paper by Gareev (2013).

Therefore, attracting a foreign investor does not necessarily safeguard its positive impact on the national or regional economy. Important determinants of absorptiveness and benefit maximisation for the local economy include technology gap, cultural and mental distance between individuals, homophily, spatial proximity, idiosyncratic character of sectors and host countries, high degree of foreign ownership, level of development of host economy, relative size of firms, degree of trade protection and the institutional framework (Tavares \& Young, 2005).

To the list of positive effects, one should also add activation of cost-sensitive mature sectors located in the proximity of less-developed territories, due to the emergence of industries in major cities. A drainage of well-educated workers and potential capital investments from the surrounding areas is one of the negative effects of the growth pole (Shanzi \& Feser, 2010).

Referring to the classical model of business location by Smith (1966), it was noted that SEZs should be a form of subsidy for investors, which aims to direct them to places that otherwise would not be of interest. These areas are located outside either the spatial boundaries or area of production profitability, or are perceived by investors as unattractive in comparison with competing locations.

Subsidised business investments in the area of SEZ should have a positive impact on the local environment through increased income and employment in other companies, 
as well as an increase in tax revenue to local governments. Grzeszczak (1999) observes that the function of the growth centre in regional development is its ability to ensure the spread effects. The spread effects occur when the core area and the periphery are incorporated to the economy through: (i) increase in demand for goods and services produced in the periphery; (ii) investments of companies from the core as a result of searching for new markets and the desire to reduce costs; (iii) income and supply multiplier effects. These effects also occur in a less tangible form, e.g. through the diffusion of styles and management patterns.

For the first time, the multiplier effects in the context of SEZ were described by Domański and Gwosdz (2005) when summarising the activities of the SSE Euro-Park Mielec. They distinguished two basic types of multiplier effects: supply and income. The supply effects arise from the extra demand created by newly established or growing enterprises, enabling the growth of companies supplying goods and services. Income effects are the result of an increase in the purchasing power of the population through increased salaries, which when spent contribute to the development of companies that meet consumers' needs. This way, the development of some companies through additional demand for products and services is 'multiplied' in the form of development of other economic entities. These entities, in turn, also create more demand, inducing another cycle of multiplier effects.

According to Domański (2001), the size of multiplier effects depends on the type of business and the size and characteristics of the company. Individual activities (industries) and companies also differ in the spatial range of multiplier effects, including the degree of local closure. Stronger local supply effects usually occur in companies that operate longer in a given location and native capital enterprises, especially those that have their own premises. Sometimes supply effects are weaker in some foreign companies, especially new factories, oriented to foreign markets. Local multiplier effects generated by outsourcing services are usually stronger than the effects arising from the supply of production. Typically, the local nature is exhibited by income multiplier effects associated with the place of residence of employees. Their size is strongly related to the number of job positions and salary levels in companies.

In the result of conducted literature studies, we found that the majority of research concentrates on SEZs positive effects stimulating economic development on the regional level. The literature lacks the sources analysing negative effects of such public aid and its impact on the local level.

In the literature, the prevailing opinion is that of the growth pole being held up as an example of positive polarisation; however, the concept of an anti-growth pole should be also introduced to draw attention to the existence of a negative polarisation associated with the overlapping in a given location of various development constraints, ultimately causing the opposite phenomenon of economic development.

Therefore, an attempt to present both aspects of polarisation offers a pioneering and fresh approach to the subject. It is important to point out under what conditions a growth pole may collapse and transform into an anti-growth pole (crater) or where and under what circumstances an anti-growth pole (crater) may come into existence in a previously non-polarised area. This is a research gap that should be filled. It may have implications for the development of studies on economic geography and regional eco- 
nomics and for practical applications as managing the state aid requires a knowledge of failure factors. It may also contribute to the formation of an early warning system to enable the planning of necessary activities aimed at avoiding a crisis.

\section{MATERIAL AND METHODS}

In Poland, special economic zones are located in 356 municipalities, which represent $14 \%$ of all municipalities (LAU2) in Poland, while the total area of economic zones does not exceed 12000 ha. There is a high geographic dispersion of the areas, as a result of which they affect the local economy significantly only in a few cases, their effect on the regional economy being rarely felt.

This may be proved by analysing the basic indexes of SEZs activity; that is, the value of investments accomplished by the companies and the number of jobs created by regional business. By the end of 2013, investment spending in the zones has surpassed 93.14 billion PLN. In 2008-2012, on an average 6\% of the annual investments in Polish enterprises were completed by regional enterprises. In the area of SEZs, 196000 new job positions were created and 70580 jobs were retained. Thus, 1.9\% of the total working population were employed in the regional enterprises.

Taking into account the nature and extent of the expected changes caused by new investments in SEZ, it is reasonable to assess whether, in the case of SEZs, flotation of multiplier mechanisms, particularly fiscal and supply, is noticed and whether SEZs became a factor which promotes economic growth at the local level. The analysis aims at answering a question whether the enterprises operating in SEZs positively influence the economic growth on the local level and thus have the ability of extending the growth to the regional level. A hypothesis was adopted for this purpose, which states that investments of subsidised entities located in SEZs should influence the local environment through the income and employment increase, as well through tax revenues for the local governments.

For this reason, we analysed the direct effects of SEZs' activity in Poland and selected indexes assessing the level of economic development of the municipalities in which the SEZs were established. For the analysis, we used data of the Ministry of Economy and Central Statistical Office of Poland regarding:

- cumulative investment spending in SEZs according to the status at the end of 2012 and 2013, when division into municipalities was conducted,

- newly created and maintained job positions in SEZs according to the status at the end of 2012 and 2013, when division into municipalities was conducted,

- the number of entities registered in the system per 1000 individuals of reproductive age between 2008 and 2013, when division into municipalities was conducted,

- the number of employees per 100 individuals of reproductive age between 2008 and 2013, when division into municipalities was conducted,

- shares of municipal budgets in taxes constituting the state budget revenue, income tax from every natural and legal person of reproductive age between 2008 and 2013, when division into municipalities was conducted. 
Based on the above-mentioned data, the following factors were evaluated:

1. internal effects based on:

- share of newly created and maintained job positions in SEZs in the number of employees in the municipality according to the status at the end of 2012 [W1],

- cumulative investment spending in PLN of regional enterprises according to the status at the end of 2012, when division into municipalities was conducted [W2],

2. external effects based on:

- the annual average growth rate of the number of entities registered in the system per 1000 individuals of reproductive age between 2008 and 2012 [T1],

- the average annual growth rate of municipal budgets in taxes constituting the state budget revenue income tax on every legal and natural persons of reproductive age between 2008 and 2012 [T2] ${ }^{1}$,

- average annual growth in the number of working people per 100 individuals of reproductive age between 2008 and 2012 [T3].

Based on such calculations, firstly we identified municipalities, which, thanks to the activity of SEZs, are able to develop faster than the sub-meso regional environment and thus act as growth centres. At the same time, as a boundary, we considered the fulfilment of two conditions regarding:

- a significant share of SEZs in the management of labour resources-the reflection of a significant impact is the W1 index at the minimum level of $10 \%$; and at the end of 2012, 86 communes met this requirement,

- significant value of new investments, i.e. such which are able to induce an effect on the regional market-according to the authors, a significant impact was observed among these municipalities for which the W2 level amounted to a minimum of 200 million PLN, by analogy to the minimum value of the large investment project in accordance with the $\mathrm{EU}^{2}$ legislation; at the end of 2012, 35 regional municipalities met this requirement.

Altogether among the 356 municipalities in general in 2012 when SEZs were completed, only 27 municipalities met the boundary conditions, leading to the hypothesis that the economic zone significantly affected their development.

Identification of municipalities with a significant level of internal effects does not allow us to conclude that these regional locations became zonal ones:

- growth pole, that is the centre of the polarised region emitting growth stimuli characterised by a higher growth rate compared to the remaining part of the region. The re-

\footnotetext{
${ }^{1}$ One of the income sources in regional municipality are shares in taxes that constitute the income of country budget. This benchmark indicates indirectly on the salary level and purchasing power of the local community and the economic condition of firms located in the regional municipality.

${ }^{2}$ Art. 100 Regulation of the European Parliament and the Council (EU) No. 1303/2013 from 17 December 2013 establishing common regulations on the European Regional Development Fund, the European Social Fund, the Cohesion Fund, the European Agricultural Fund for the Rural Area Development and the European Maritime Fund and Fisheries and establishing general regulations on the European Regional Development Fund, the European Social Fund, the Cohesion Fund and the European Maritime and Fisheries Fund and repealing Council Regulation (WE) No 1083/2006 (L 347/320).
} 
gion may be applied to spatial units of different levels of taxonomic division (e.g. local, meso-regional, macro-regional) ${ }^{3}$,

- anti-growth pole that is a centre of the polarised region emitting crisis stimuli of higher growth rate compared to the remaining part of the region.

The answer to this question is possible only on the basis of an assessment of external effects, which reflect the supply effects $\left(T_{1}\right)$ and income effects $\left(T_{2}, T_{3}\right)$. In order to accomplish that, we compared $T_{1}, T_{2}, T_{3}$ indices of each municipality that had a SEZ within its border with the same indices of a local government of a higher level, i.e. district, subregion, or region depending on the municipality status according to NTS.

The period which was considered when calculating average annual growth rate for the purpose of $T_{1}, T_{2}, T_{3}$ calculation, is similar to the permanence period required for projects supported from public funds under the guidelines on national regional investment aid ${ }^{4}$. Results of the calculations are presented in Table 1.

Depending on the level of $T_{1}, T_{2}, T_{3}$ index, following delimitation criteria were established: poles ( $T 1, T_{2}, T_{3}$, greater than zero), anti-poles $\left(T_{1}, T_{2}, T_{3}\right.$, equal to zero or less) and the centres of unstable growth rate $\left(T_{1}, T_{2}, T_{3}\right.$ above or below zero) (Table 2$)$.

Then, econometric analysis was carried out analysing the type of polarisation that occurs in the regional municipalities and investment attractiveness of communes, where special economic zones are found. For this purpose, the index of potential investment attractiveness developed by Godlewska-Majkowska (2012) was used ${ }^{5}$.

\footnotetext{
${ }^{3}$ This definition refers to the concept of growth poles by Perroux (1955).

${ }^{4}$ EC regulation on regional aid for 2014-2020 (Text which is relevant for EOG) (2013/C 209/01).

${ }^{5}$ Potential investment attractiveness is an approach referring to the assessment of localisation prior to investment. In this perspective, location advantages are analysed. The construction of indexes describing potential investment attractiveness refers to the leading location factors, grouped into components describing demographic and marketing factors, as well as technical and social infrastructure and pro-investment behaviour of local governments. In addition, according to the accessibility to the data, research and development issues, as well as social capital (relational) are considered.

The advantage of this index is the design enabling full comparability of ratings of investment attractiveness at all levels of the static division of the country. The disadvantage is the limitation regarding a set of diagnostic variables, due to the need of their accessibility for all levels of the static distribution of the country. Despite these difficulties, this index is based on 45 diagnostic variables, which appear to be a sufficiently broad foundation for comparisons. All indexes are calculated based on weight-correlation method, allowing determination of weights of pseudo-attribute variables based on the statistical distribution, which minimizes the subjectivity of the final evaluations.

The method adopted allows for minimising the effect of subjective assessment of the author on the final results, while taking into account the uneven impact of individual variables on the size of the final index. It corresponds to reality to a greater extent compared to exclusion of ranks of residual variables.

The calculated values of the synthetic pseudo-attribute index form the basis of a subset to the set of spatial units of $A F$ classes, the scope of which was determined by the left-closed intervals with the following lower boundaries: Class A: Av $+S(x)$, Class B: Av $+0.5 S(x)$, Class C: Av, Class D: Av-0.5S(x), Class E: Av-S(x), Class F: 0 , where $A v$ - arithmetic mean, $S(x)$ - standard deviation.

The design of indexes also allows for their decomposition to the level of sub-aggregates, so that each territorial unit may be assessed in terms of the attractiveness included in each microclimate (labour resources, technical infrastructure, social infrastructure, market sale and administration). If necessary, it is possible to explore the profile of the particular unit and to determine the formation of source variables in particular locations. For further details see Godlewska-Majkowska (2012).
} 
Table 1. United States Case Studies of Immigrant Entrepreneurs as boundary spanners

\begin{tabular}{|c|c|c|c|c|c|c|c|}
\hline Municipality & Province & SEZ & $w_{1}$ & $\mathbf{w}_{2}$ & $\mathrm{~T}_{1}$ & $\mathbf{T}_{2}$ & $T_{3}$ \\
\hline Polkowice (3) & DOLNOŚLĄSKIE & Legnicka & $22 \%$ & 3156650621.00 & 0.62 & 3.87 & 0.05 \\
\hline Legnickie Pole (2) & DOLNOŚLĄSKIE & Legnicka & $21 \%$ & 433540367.00 & 0.27 & 2.25 & 8.57 \\
\hline Nowogrodziec (3) & DOLNOŚLĄSKIE & Kamiennogórska & $18 \%$ & 1143716511.99 & 0.92 & 0.60 & 2.01 \\
\hline Jelcz-Laskowice (3) & DOLNOŚLĄSKIE & Wałbrzyska & $18 \%$ & 1486475875.01 & 0.68 & 0.34 & 0.39 \\
\hline Głogów Małopolski (3) & PODKARPACKIE & Mielecka & $14 \%$ & 271736177.00 & 1.13 & 2.77 & 5.40 \\
\hline Ksawerów (2) & ŁÓDZKIE & Łódzka & $12 \%$ & 218804551.29 & 0.61 & 4.93 & 4.45 \\
\hline Nowe Skalmierzyce (3) & WIELKOPOLSKIE & Łódzka & $11 \%$ & 358933777.00 & 2.86 & 3.15 & 3.27 \\
\hline Kobierzyce (2) & DOLNOŚLĄSKIE & Tarnobrzeska/ Wałbrzyska & $93.94 \%$ & 4150382000.00 & 2.13 & 0.57 & -0.02 \\
\hline Mielec (1) & PODKARPACKIE & Mielecka & $32.22 \%$ & 3536834799.00 & -0.28 & 0.31 & 0.00 \\
\hline Wielbark (2) & WARMIŃSKO-MAZURSKIE & Warmińsko-Mazurska & $30.30 \%$ & 260842760.00 & -1.50 & 7.27 & 10.79 \\
\hline Kostrzyn nad Odrą (1) & LUBUSKIE & Kostrzyńsko-Słubicka & $25.91 \%$ & 1083524606.88 & -1.31 & -2.69 & 1.32 \\
\hline Żarów (3) & DOLNOŚLĄSKIE & Wałbrzyska & $22.45 \%$ & 919040617.30 & 0.89 & -0.57 & 1.11 \\
\hline Skarbimierz (2) & OPOLSKIE & Wałbrzyska & $22.33 \%$ & 1301710921.60 & 2.02 & -1.66 & 25.14 \\
\hline Stalowa Wola (1) & PODKARPACKIE & Tarnobrzeska & $13.73 \%$ & 1118906400.00 & -0.24 & -0.57 & 0.53 \\
\hline Piechowice (1) & DOLNOŚLĄSKIE & Kamiennogórska & $12.55 \%$ & 238079233.14 & -2.20 & 3.50 & -0.61 \\
\hline Tychy (1) & ŚLĄSKIE & Katowicka & $12.07 \%$ & 3271164639.79 & 0.28 & -0.57 & 0.02 \\
\hline Ozorków (1) & ŁÓDZKIE & Łódzka & $11.83 \%$ & 532669610.93 & -1.55 & 0.64 & -1.43 \\
\hline Starachowice (1) & ŚWIĘTOKRZYSKIE & Starachowicka & $11.73 \%$ & 616628829.00 & -0.39 & 0.29 & 1.14 \\
\hline Kwidzyn (1) & POMORSKIE & Pomorska & $11.62 \%$ & 1079030205.00 & -0.28 & 0.85 & -0.53 \\
\hline Nowa Dęba (3) & PODKARPACKIE & Tarnobrzeska & $11.33 \%$ & 325516900.00 & -0.10 & 1.07 & 2.30 \\
\hline Krotoszyn (3) & WIELKOPOLSKIE & Wałbrzyska & $10.32 \%$ & 415155000.00 & -0.14 & 0.34 & 0.07 \\
\hline Barlinek (3) & ZACHODNIOPOMORSKIE & Kostrzyńsko-Słubicka & $10.06 \%$ & 426665776.08 & -0.14 & -1.23 & 0.49 \\
\hline
\end{tabular}

Source: http://www.ilctr.org/promoting-immigrants/immigrant-entrepreneurship/video-interviews/ 
Based on Gretl statistical program, we analysed the correlations between the effects of external economic zones (based on the average of W1 and W2 variables) and:

- index of potential investment attractiveness for the local economy,

- particular aggregated data describing each individual key location factors (labour resources, technical infrastructure, social infrastructure, market sales, administration),

- all variables building the local attractiveness of individual municipalities (matrix of dimensions $78 \times 78$ was analysed) where economic sub-zones were formed.

Statistical analysis using the Gretl program revealed no significant correlation, expressed by the index of potential investment attractiveness, between the nature of the polarisation and localisation values of Polish regions, as well as for the remaining sections of the analysis. Statically significant correlation (positive) was observed between external effects, zone and local development plan of individual municipalities. At the same time a negative correlation was reported in analogy in terms of accessibility to health care (number of consultations per 1000 inhabitants, accessibility to pharmacies per 1000 inhabitants).

The first statistical correlation obtained is confirmed when considering the organization of the investment process; if in a given municipality, properties are covered by the local development plan, then the investment process is not delayed due to waiting for the decision on conditions for construction and land management.

The second correlation, a negative one, indicates the importance of accessibility for people with relatively good health status, which is understandable considering the specialisation of Polish special economic zones in the manufacturing industry.

Table 2. Criteria for the delimitation of the poles and the anti-poles in the area of regional municipalities

\begin{tabular}{|l|c|c|c|c|c|}
\hline \multicolumn{1}{|c|}{ Category/criterion } & $\mathbf{W}_{\mathbf{1}}$ & $\mathbf{W}_{\mathbf{2}}$ & $\mathbf{T}_{\mathbf{1}}$ & $\mathbf{T}_{\mathbf{2}}$ & $\mathbf{T}_{\mathbf{3}}$ \\
\hline POLE & $>=10 \%$ & $>=200 \mathrm{MM}$ PLN & $>0$ & $>0$ & $>0$ \\
\hline ANTI-POLE & $>=10 \%$ & $>=200 \mathrm{MM} \mathrm{PLN}$ & $<0$ & $<0$ & $<0$ \\
\hline UNPOLARISED CENTRE & $>=10 \%$ & $>=200 \mathrm{MM}$ PLN & $<0$ or $>0$ & $<0$ or $>0$ & $<0$ or $>0$ \\
\hline
\end{tabular}

Source: own study.

\section{RESULTS AND DISCUSSION}

Among 27 municipalities meeting the boundary criteria, on the basis of external effects criteria, we identified 8 growth poles and 19 centres of unstable economic situation; the anti-growth pole was not identified. Growth poles are located mainly in southwestern Poland (Polkowice, Legnickie Pole, Nowogrodziec, Jelcz-Laskowice) and one pole in each of the other parts of Poland (Glogow Malopolska, Nowe Skalmierzyce, Gliwice, Ksawerów).

Analysis of cartograms does not indicate a straightforward relation between location and the nature of polarisation (Figure 1). One can only observe the spatial concentration of the poles in southern Poland, which is associated with supply networks for the automotive sector. In addition, it may be related to the distribution of Polish industrial districts, focusing on the southern area from the NUTS2 region of Lower Silesia, through 
Silesian, Małopolskie, to Subcarpathian. Regional poles generally occurred in urban-rural municipalities, i.e. those where there is a small town with surrounding rural areas. They are often located in the areas that were formerly industrial centres manufacturing commodities or in urban areas. In that case, the polarisation effect is possible as a result of free investment areas, enabling further investments based on cooperative relationships and low cost of doing business. In addition, there are no other significant sources of agglomeration benefits, typical of urban environment.

Analysis of structure of the trade economy indicates an association between the formation of poles and the regional specialisations supply network. Among the growth poles, we distinguished those that arose based upon investments completed by automotive industry companies (Polkowice, Legnickie Pole, Jelcz-Laskowice, Gliwice) and those that adopt a spatial model based on investments of leading entity cooperating with entities outside the zone (Nowe Skalmierzyce) or investments of many entities cooperating together in the supply network (Nowogrodziec, Jelcz-Laskowice, Głogów Małopolski, Gliwice).

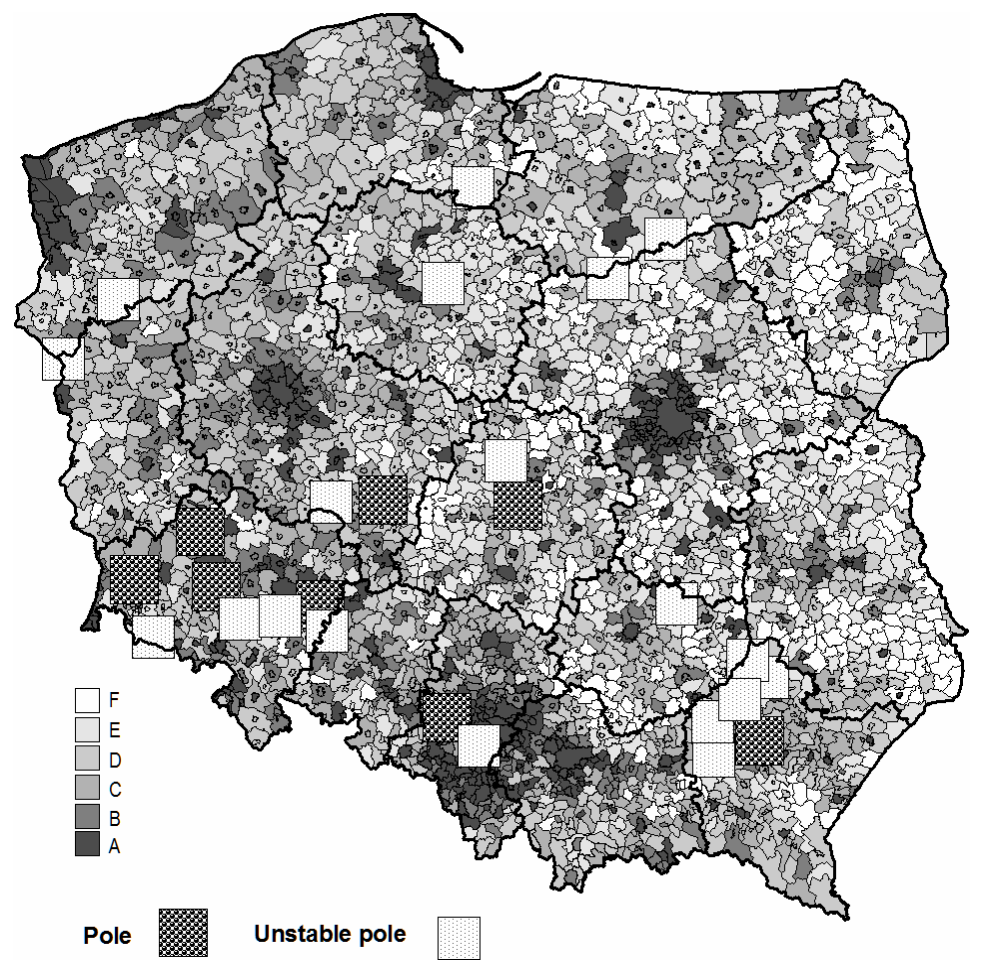

Figure 1. Distribution of regional poles in Poland in 2012 against the investment attractiveness of municipalities Source: own elaboration based on self-reported data.

The proposed method of identification of growth and anti-growth poles may be used not only to evaluate the effects of SEZs on regional development, but also to assess the impact of various forms of public aid on the region's economy, e.g. clustering and networking, subsidies for investments, support of entrepreneurship development etc. 
Due to the fact that conclusions regarding the presence of poles and anti-poles should be verified using qualitative methods, our methodological procedure was supplemented by in-depth interviews addressed to the management of five among the fourteen special economic zones established in Poland.

From the results of the study, the following key factors were considered as necessary for stimulating the local and regional economic development: large scale of the investments to induce the effect in the local/regional economy, entry to the zone of an important investor and doing business with a high investment multiplier. To these very important factors, we can also include the presence and the quality of the business environment, a high level of economic development of the host region and adaptation of the industry to the host region (including business activities in accordance with the investment potential of the parent region and corresponding to the specificity of place in terms of the size and structure of resources) as well as strong relations with the local business.

Important factors of positive impact of SEZs on the local or regional economy appeared to be (i) lack or limited power of the decision-making centres (e.g. large independence of regional companies in the structure of the corporation) and (ii) presence of linkages and associations as elements providing benefits from the parent unit to the stimulated units. The least important role was assigned to geographical and cultural proximity of enterprises investing their business in the area of SEZ.

In the course of the conducted studies it was noted that the most important factors of economic zones that affect the positive polarisation of regional development are:

- entry of an important investor into the area and the large scale of investment exerting an effect on the local and regional economy, e.g. in the areas of Legnickie Pole, Gliwice, Jelcz-Laskowce-the automotive industry,

- embedding of business, resulting in conducted reinvestments in the zone proving the positive impact of location in SEZ on the company's objectives-e.g. it applies to the poles such as Legnickie Pole, Polkowice, Głogów Małopolski; Nowe Skalmierzyce, Jelcz-Laskowice, Gliwice,

- technological advancement of regional companies, particularly important are innovations on a global scale, facilitating the export of products or business relations with a foreign corporation (new technologies which relate to thermomanagement, i.e. for Volkswagen and Audi).

Study results suggest that for the most important factors negatively affecting the local and regional economic development, we can name abandonment of the zone by the leading investor, insufficient quantity and quality of business entities' environment, the presence of linkages and associations as transmitters transferring the crisis from the parent unit to the stimulated ones and low level of economic development of the host region. In this context, decision-making instability and dependence of enterprises in the zone on foreign decision-making centres are also important. Other important factors include permitting small-scale investment, generating no significant effects in the local/regional economy, doing business of low investment multiplier, cultural distance and lack of adjustment of the industry to specificity of the host region.

In one of the analysed zones, withdrawal of strategic investors for the purpose of its development was observed due to unsatisfactory economic performance of the company, the global economic crisis or a strategic decision made by the decision centre located 
outside the country. Despite this, in the analysed SEZ, no remedial program or any procedures which can be run during an emergency situation, e.g. related to the abandonment of the zone by an important investor, was mentioned.

An important role is certainly played by the active attitude of management zones and local and regional authorities, towards investors already operating in the area, in the form of additional incentives to reinvest in the area of SEZ. Among the activities of this type, we can mention business-related services, workshop offers, networking meetings, seminars, conferences, foreign missions and fairs, supporting clusters' activity and networking.

Generally speaking, it can be concluded that qualitative research confirmed the existence of poles in the targeted locations and confirmed the lack of anti-pole disclosure over the considered period. On one hand, this may be explained by the small size of Polish investments in the zones, and thus a domino effect is questioned. This resulted mainly from efforts aimed at developing labour resources released as a result of redundancies. It is favoured by spatial organization of zones characterised by the territorial dispersion. In the face of global crisis, particularly the one in 2009 that affected the Polish economic zones, the expression of solidarity between the particular zone managements was evident in their efforts to generate new job positions in other locations within the economic zone for workers who were about to lose their jobs.

The question arises, to what extent can this method be applied in economic zones with a different organizational structure to that in Poland. Throughout the world, public aid offered in the zones takes several forms (exemption from customs duty, exemption from income tax, investment funding, giving the premises for infrastructure usufruct on better than market conditions, investment guarantees, administrative privileges) and depends on the generation of the zone (commercial areas, production zones, service areas, research areas, competitive zones, transnational areas).

Despite this diversity, the expected short-term goals of SEZs activity are similar (inflow of investments, new job positions). However, the objective of the zones from the point of view of regional inequality is not and cannot be the inflow of investment alone. What is expected from the zones in a long-term perspective relates to structural changes in the regional economy, diversification of economic activities, technology transfer, networking of foreign investors from the zones with the national economy and increased mobility of labour resource from the area to the rest of the region/country to establish the diffusion of knowledge and skills.

New investments and new job positions as well as faster development of administrative centre are the direct effects of the zones. Thus, the proposed method of evaluation of changes induced at the location of economic zones exemplified by SEZs in Poland is very universal. It allows assessing the impact of various forms of economic zones on the economy of the region/country, regardless of the initial level of socioeconomic development of a particular country or the zone.

Depending on the size of the economy of a particular country, the dispersion of zone's location, size of the administrative areas covered by the privileges, boundary criteria relating to the minimum value of investment spending in the zone and minimal participation in the use of labour resources, as well as the reference area in relation to which growth effects will be studied, should be factored into the methodology of future 
studies. In contrast, the selection of indexes $\left(T_{1}, T_{2}, T_{3}\right)$ on the basis of which one assesses the occurrence of polarisation effects can be similar due to the fact that they reflect the emergence of income and supply multiplier effects that determine the polarisation of the economic space.

\section{CONCLUSIONS}

In order to ensure the sustainability of development throughout an area, it is necessary to develop a concept of zone activities, which will provide the conversion of their structures in the new industrial spaces. A well designed and consistently implemented SEZ policy can bring the desired results, i.e. increase employment, foreign investments and increase of exports. Poorly executed program for the zones can result in negative outcomes, such as reduction of the tax base and low "quality" of investments, which are unstable and weakly associated with the economic and social environment of the zone. It results from the fact that the special economic zones can cause both positive and negative polarisation of regions.

Positive polarisation in the form of a growth pole occurs whenthe zone is entered by, a large company or co-operating companies (e.g. cluster), characterised by the following features: (i) the ability to elicit regressive and progressive feedbacks, (ii) scale large enough to produce a substantial economic effect, (iii) doing business with high investment multiplier, (iv) strong associations with the local business ecosystem, (v) lack or limited power of the decision-making centres (e.g. large independence in the corporate structure), (vi) doing business in accordance with the investment potential of the parent region.

To induce long-lasting effects exerted by these characteristics, favourable conditions created by regional, national and international environments (within their competencies) are necessary, such as stability of regulations and generation of the anticipated attractive investment areas, thanks to which it is possible to reduce the capital of investment spending expenditure and the time taken to obtain income from business activity.

An economic zone can become the origin of a new industrial space. For this to happen, the zone should be created based on the dominance of one, or more external investors, private or public, together with a set of small- and medium-sized enterprises. External investors should be guarantors of innovative, technologically advanced activity, and small- and medium-sized enterprises should act as a guarantee of the use of endogenous potential. Entities located within and in close proximity to the area should cooperate with each other in a competitive environment to discount the external benefits, i.e. the advantages of specialisation, enabling the achievement of high competencies within the process phases regarding the product manufacture and scale effect, diffusion of innovations as a result of exchange of information and knowledge through mobile personnel and benefits of access to qualified personnel.

External benefits are related to the requisite presence of business environment institutions, such as R \& D units, technology transfer centres and financial institutions. The confluence of these conditions will lead to the evolution of economic zones in clusters or industrial districts. The joint incidence of the above-mentioned conditions is essential for inducing the development of growth poles in the regional environment as a result of regional multiplier effects. 
The pole may be subject to "collapse" or anti-poles may occur in a so far unpolarised region, if (i) economic zones compete with each other rather than cooperate based on competition, creating an excessive number of economic zones, which leads to their excessive dissipation, (ii) regional companies do business ill-suited to the location specificity in terms of size and structure of the resources, as well as excessive cultural distance, (iii) economic zone develops at the expense of the environment, absorbing the factors of production resources, (iv) regional companies establish stronger relations between themselves resigning from the cooperation with local business partners, (v) leading company forming a chain of cooperative relations withdraws from the economic zone, (vi) regional enterprises are unstable in decision making, and not self-reliant in relation to foreign decision-making centres, (vii) feedbacks and associations are responsible for transferring the crisis from the leading unit to the stimulated units, (viii) in the direct vicinity of zones, there is a lack of enterprises ready to establish cooperation, (ix) local resources, especially labour resources are insufficient in terms of both quantity and quality, $(x)$ laws regarding the running of business in the zone are unclear or unstable. If the above-mentioned negative phenomena occur simultaneously, then a phenomenon of negative synergy takes place. The sum of adverse circumstances acts stronger than each of them separately.

In Poland, cases of inhibition of local subzone development, which lost their strategic investors (lack of investment in the assumed time or withdrawal of permission due to non-compliance of investment with permission conditions) were observed. However, it did not exhibit the character of a collapse of a pole, but rather scratching a weak antipole development, which lost the ability to polarise space over time.

Withdrawal of investors from the zone has an adverse effect not only on the investment potential of the area, but also promotes a negative social phenomena, such as the inhibition of entrepreneurship, the emergence of counterproductive behaviour and "schadenfreude" (malicious joy). It is intensified when there is no economic justification for such decision, and is based on political factors or strategic decisions established at higher levels of the organizational structure of the corporation.

Among the currently operating growth poles in Poland, a characteristic, strong specialisation is observed in the automotive industry. One should avoid monocultural development of areas, especially changing the rules of public aid during the course of longterm economic networking, breaking down the previous lock-in and lock-out of regions. This type of model development, to a great extent, threatens the development of antipoles as a result of the collapse of the anti-growth pole.

Inflow of investments, which does not induce profit and supply multiplier effects and consequently does not lead to polarisation of space, may indicate that inflow of new investments is inadequate to the needs of the region, or industrial structure of new investments is not adapted to the potential of the region and its endogenous potential as well, or new investments do not create associations with the economy of the region.

Lack of polarisation may be the result of a bad location of the zone or improper determination of conditions of running business within the zones, which consequently leads to the the following effects:

- neutral gear - some investments in SEZ would arise in the region, even in the absence of SEZ within their area, or any opportunities to obtain tax exemptions; this reduces 
the incentive effect generated by subsidies for less-developed regions. In this way, one reduces the investment attractiveness of the subsidised area, which was originally located outside the spatial boundaries of profitability. However, in contrast to the initial situation, much greater benefits are reached by investors due to reduced operating costs in the area within the boundaries of profitability, and the budget loses due to smaller tax revenues,

- substitution - the gradual transfer of business from outside the area to within the zone (and in accordance with the authorisation), thereby reducing or eliminating existing business outside the privileged area,

- displacement - assistance for businesses in SEZ, due to costs of reduction and their operation, may contribute to the displacement of public entities, which are not covered by public aid,

- enclaves - enterprises from the zone use tax exemptions and cheap labour resources, but acquire business partners located outside the region, where they also sell manufactured goods.

In such a situation, positive effects resulting from the SEZ functioning in the region are basically limited to reduction of the level of unemployment. Formation of economic zones should be supported by complementary actions in relation to tax preferences, i.e. generation of associations and cooperation with the business environment. Support from the public funds should not be limited to homogeneous forms of assistance in the form of subsidies, or tax exemptions, but should sign in to wider financial activities from the public funds.

Establishing favourable conditions for running a business in the form of a special economic zone entails a risk that may have negative effects for regional development and formation of investment attractiveness of the region. External investors, who decided to invest in the zone, may constitute the source of risk. Their negative impact on regional development results from deepening of monoculture, provisional state of activity, lack of innovation, not adjusting to the specific nature of the environment or loss of the ability to fulfil the conditions of the permission. The surrounding area may also constitute a source of risk, especially unclear or unstable laws, lack of technological absorption, low level of development of entrepreneurship and local business partners and adjusting the resources of production to investor's needs. Moreover, the risk can be created by the spatial structure of the zone. It occurs when the privileged area is not defined properly, and there is a lack of relevant partners essential for cooperation (leading entities, lack of small- and medium-sized enterprises, research and development institutions, business environment institutions).

The above-mentioned source of investment risk, in most cases, results from the lack of implementation of the conditions necessary to achieve the growth and development of the investment attractiveness of the SEZ.

Numerous risks associated with the formation of special economic zones and antigrowth poles therefore require the use of a system for monitoring changes in the local and regional economy. Our model captures the growing changes and implements the preventive actions aimed at protecting job positions and facilitating the transfer of released labour resources as a result of lost jobs in the economic zones. This phenomenon may occur not only at the local level, as exemplified in the Polish areas, but also in larger 
regions. The method proposed in this paper may be used at different levels of taxonomic divisions, bearing in mind that the critical size of the investment, which separates the small from the large zones, must be adjusted appropriately to the scale of the concentration of business activity and the size of the region stimulated by the zones.

One of the limitations of the proposed research method, is the fact that the research was acrreied out during a specified period of time, without taking into account effects of earlier, or later investments. We make an assumption, simplifying the case, that the analysed investments have not started before the conducted analysis. This error will be present for any analysed period. In order to eliminate this effect, one can use the 5-year analysis period with a 1-year shift. It would allow creating a changes monitoring system, using a proper level of taxonomic system for establishing a spatial scale for observations (not only in the LAU2 scale, as it is used in Poland, due to the low scale of Polish special economic sub-zones). It points to the further need of research concerning dynamic aspects' use in the proposed method.

\section{REFERENCES}

Ambroziak, A.A. (2009). Krajowa pomoc regionalna w specjalnych strefach ekonomicznych $w$ Polsce. Warsaw: Warsaw School of Economics Press.

Boudeville, J.R. (1972). Aménagement du territorire et polarization. Paris: Editions M.-Th. Génin.

Brautigam, D., \& Xiaoyang, T. (2011). African Shenzhen: China's Special Economic Zones in Africa. The Journal of Modern African Studies, 49(1), 27-54.

Brdulak, J. (2003). Ewolucja uprzywilejowania ekonomicznego specjalnych stref ekonomicznych w Polsce In I. Fierla (Ed.), Regionalne aspekty rozwoju wybranych rodzajów działalności gospodarczej w Polsce (pp. 69-80). Warsaw: Warsaw School of Economics Press.

Broszkiewicz, P. (2011). Odpływ kapitału inwestycyjnego ze specjalnych stref ekonomicznych zlokalizowanych w województwie dolnośląskim - implikacje społeczno-ekonomiczne. Prace Naukowe Uniwersytetu Ekonomicznego we Wrocławiu, 152, 25-36.

Christensen, C.M., \& van Bever, D. (2014). The Capitalist's dilemma. Harvard Business Review, 92(6), 60-68.

Churski, P. (2011). Obszary wzrostu i obszary stagnacji gospodarczej w Polsce - kontekst teoretyczny. Biuletyn KPZK PAN, 248, 9-43.

Domański, B., \& Gwosdz, K. (2005). Dziesięć lat doświadczeń pierwszej polskiej specjalnej strefy ekonomicznej. Kraków-Mielec: Instytut Geografii i Gospodarki Przestrzennej Uniwersytetu Jagiellońskiego w Krakowie, Agencja Rozwoju Przemysłu S.A.

Domański, B. (2001). Kapitał zagraniczny w przemyśle Polski. Prawidłowości rozmieszczenia, uwarunkowania i skutki. Cracow: Jagiellonian University in Cracow.

Farole, T. (2011). Special Economic Zones in Africa: Comparing Performance and Learning from Global Experiences. Washington: World Bank.

Fierla, I. (2000). Narastanie przestrzennych dysproporcji rozwojowych w Polsce. In J. Brdulak (Ed.), Przedsiębiorstwo $w$ regionalnym środowisku innowacyjnym XXI wieku (pp. 103-118). Warsaw: Polskie Towarzystwo Ekonomiczne.

Gancarczyk, J., \& Gancarczyk, M. (2002). Konkurencyjność skupisk przemysłu (clusters) - od korzyści zewnętrznych do korzyści sieci. Studia Regionalne i Lokalne, 2-3(9), 75-90. 
Gareev, T. (2013). The special economic zone in the Kaliningrad region: development tool or institutional trap? Baltic Journal of Economics, 13(2), 111-127.

Godlewska-Majkowska, H. (Ed.) (2012). Atrakcyjność inwestycyjna regionów Polski jako źródło przedsiębiorczych przewag konkurencyjnych. Studia i Analizy Instytutu Przedsiębiorstwa. Warsaw: Warsaw School of Economics.

Gorzelak, G., \& Jałowiecki, B. (2000). Konkurencyjność regionów. Studia Regionalne i Lokalne, 1, 7-24.

Grzeszczak, T. (1999). Bieguny wzrostu a formy przestrzeni spolaryzowanej. Prace Geograficzne, 173, 11-14.

Hajduga, P. (2011). Oddziaływanie specjalnych stref ekonomicznych na rozwój społecznogospodarczy Dolnego Śląska w pierwszej dekadzie XXI wieku. Biblioteka Regionalisty, 11, 65-79.

Hirschman, A.O. (1958). The Strategy of Economic Development. New Haven: Yale University Press.

Hsu, M-S., Lai, Y.L., \& Lin, F-J. (2013). Effects of Industry Clusters on Company Competitiveness: Special Economic Zones in Taiwan. Review of Pacific Basin Financial Markets and Policies, 16(3), 1-28.

Jarczewski, W. (2007). Specjalne strefy ekonomiczne w gminach. Samorzqd Terytorialny, 7-8, 89-96.

Kryńska, E. (2000). Polskie specjalne strefy ekonomiczne - zamierzenia i efekty. Warsaw: Wydawnictwo Naukowe Scholar.

Krzemiński, P. (2009). Specjalne strefy ekonomiczne jako stymulator przedsiębiorczości. Przedsiębiorczość - Edukacja, 5, 218-227.

Lai, Q. (2006). Corporate Social Responsibility of SMEs in China: Challenges and Outlooks. Berichte des Arbeitsbereichs Chinaforschung 18, Institut für Weltwirtschaft und Internationales Management der Universität Bremen und Internationaler Studiengang Volkswirtschaft, Hochschule Bremen, 1-32.

Laskowski, P. (2013). Specjalne strefy ekonomiczne jako czynnik rozwoju regionalnego na przykładzie wałbrzyskiej specjalnej strefy ekonomicznej "INVESTPARK". Prace Naukowe Uniwersytetu Ekonomicznego we Wrocławiu, 307, 317-329.

Leong, C.K. (2013). Special economic zones and growth in China and India: an empirical investigation. International Economics and Economic Policy, 10, 549-567.

Lizińska, W., Marks-Bielska, R., \& Kisiel, R. (2011). Atrakcyjność inwestycyjna gmin i znaczenie w jej kształtowaniu preferencji specjalnej strefy ekonomicznej. Roczniki Nauk Rolniczych Seria G, 98(3), 191-204.

Mckee, D.L. (1987). On Services and Growth Poles in Advanced Economies. The Service Industries Journal, 7(2), 165-175.

Miłaszewicz, D. (2011). Specjalne strefy ekonomiczne jako narzędzie modernizacji gospodarki. Studia i Prace Wydziału Nauk Ekonomicznych i Zarzqdzania, 22, 7-34.

Moura, R., \& Forte, R. (2010). The Effects of Foreign Direct Investment on the Host Country Economic Growth - Theory and Empirical Evidence. Fep Working Papers, 390, 1-32.

Myrdal, G., (1957). Economic theory and under-developed regions. London: Duckworth.

Nazarczuk, J.M., \& Kisiel, R. (2013). Postrzeganie pomocy publicznej w SSE jako instrumentu pozyskiwania bezpośrednich inwestycji zagranicznych. Acta Universitatis Nicolai Copernici, Ekonomia, XLIV, (1), 7-16. 
Ofiarska, M. (2000). Specjalne strefy ekonomiczne w Polsce. Zagadnienia publicznoprawne. Rozprawy i Studia Uniwersytetu Szczecińskiego, 346, 317-342.

Osinubi, T.C., \& Amaghionyeodiwe, L.A. (2010). Foreign Direct Investment and Economic Growth in Nigeria. Review of Economic Business Studies, 3(1), 105-127.

Paelinck, J. (1965). La théorie du développement regional polarisé. Paris: Cahiers de L'I.S.E.A., 159, 5-47.

Park, B.-G. (2005). Spatially Selective Polarization and Graduated Sovereignty: Politics of NeoLiberalism and "Special Economic Zones" in South Korea. Political Geography 24(7), 850-873.

Parr, J.B. (1999a). Growth-pole Strategies in Regional Economic Planning: A Retrospective View. Part 1. Origins and Advocacy. Urban Studies, 36(7), 1195-1215.

Parr, J.B. (1999b). Growth-pole Strategies in Regional Economic Planning: A Retrospective View. Part 2. Implementation and Outcome. Urban Studies, 36(8), 1247-1268.

Pastusiak, R. (2011). Specjalne Strefy Ekonomiczne jako stymulator rozwoju gospodarczego. Łódź: University of Łódz Press.

Perroux, F. (1955). Note sur la notion de „Pole de Croissancie”. Economie Applique, 8(1-2), 307-320.

Pilarska, Cz. (2009). Specjalne strefy ekonomiczne w Polsce. Cracow: Cracow University of Economics.

Przybyła, K. (2010). Wpływ specjalnych stref ekonomicznych na kształtowanie się bazy ekonomicznej miast. Wrocław: Wrocław University of Environmental and Life Sciences Press.

Saqib, N., Masnoon, M., \& Rafique, N. (2013). Impact of Foreign Direct Investment on Economic Growth of Pakistan. Advances in Management \& Apllied Economics, 3(1), 35-45.

Shanzi, KE., \& Feser, E. (2010). Count on the Growth Pole Strategy for Regional Economic Growth? Spread-Backwash Effects in Greater Central China. Regional Studies, 44(9), 1131-1147.

Shen, Y. (2007). Entrepreneurship corporate social responsibility and flexible innovation networks: On the interaction between TNCs' R\&D activities and local development. Chinese Business Review, 6(6), 1-12.

Shi, H., Chertow, M., \& Song Y. (2010). Developing country experience with eco-industrial parks: a case study of the Tianjin Economic-Technological Development Area in China. Journal of Cleaner Production, 18(3), 191-199.

Sigler, T.J. (2014). Panama's Special Economic Zones: Balancing Growth and Development. Bulletin of Latin American Research, 33(1), 1-15.

Smith, D. (1966). A theoretical framework for geographical studies of industrial location. Economic Geography, 42, 95-113.

Tavares, A.T., \& Young, S. (2005). FDI and multinationals: patterns, impacts and policies. International Journal of the Economics of Business, 12(1), 3-16.

Tödtling, F., Asheim, B., \& Boschma, R. (2013). Knowledge sourcing, innovation and constructing advantage in regions of Europe. European Urban and Regional Studies, 20(2), 161-169.

Typa, M. (2012). Specjalne strefy ekonomiczne jako bieguny rozwoju lokalnego. In H GodlewskaMajkowska (Ed.), Atrakcyjność inwestycyjna regionów Polski jako źródło przedsiębiorczych przewag konkurencyjnych. Studia i Analizy Instytutu Przedsiębiorstwa (pp. 142-173). Warsaw: Warsaw School of Economics.

Typa, M. (2013a). Polskie specjalne strefy ekonomiczne na tle stref działających w innych krajach Unii Europejskiej. In H. Godlewska-Majkowska (Ed.), Atrakcyjność inwestycyjna regionów Pol- 
ski na tle Unii Europejskiej. Studia i Analizy Instytutu Przedsiębiorstwa (pp. 109-126). Warsaw: Warsaw School of Economics.

Typa, M. (2013b). Specjalne strefy ekonomiczne w Polsce jako stymulator konkurencyjności regionów. Kwartalnik Nauk o Przedsiębiorstwie, 27(2), 16-25.

Willmore, L. (1995). Export Processing Zones in the Dominican Republic: A Comment on Kaplinsky. World Development, 23(3), 529-535.

Wong, K.-Y., \& Chu, D.K.Y. (1984). Export Processing Zones and Special Economic Zones as Generators of Economic Development: The Asian Experience. Geografiska Annaler, 66(1), 1-16.

Zeng, D.Z. (2011). How Do Special Economic Zones and Industrial Clusters Drive China's Rapid Development? Policy Research Working Paper, 5583, The World Bank.

Zhao, S.X., Chan, R.C.K., \& Chan, N.Y.M. (2012). Spatial polarization and dynamic pathways of foreign direct investment in China 1990-2009. Geoforum, 43(4), 836-850.

\section{Authors}

The contribution of co-authors is equal and can be expressed as $33 \%$ each of the authors.

\section{Hanna Godlewska-Majkowska}

Professor of Economics at Warsaw School of Economics (Poland). Her research interests include: regional economy, business geography, regional entrepreneurship, business location and operational management.

Correspondence to: Prof. dr hab. Hanna Godlewska-Majkowska; Warsaw School of Economics, Institute of Enterprise; al. Niepodległości 162, 02-513 Warszawa, Poland; e-mail: hanna.godlewska@sgh.waw.pl

\section{Agnieszka Komor}

PhD. in Economics. Assistant Professor at the University of Life Sciences in Lublin (Poland). Her research interests include: institutional support for investors and entrepreneurs, regional and local development, spatial aspects of the enterprises' competitiveness, bioeconomy.

Correspondence to: Dr Agnieszka Komor; University of Life Sciences in Lublin, Department of Management and Marketing; ul. Akademicka 13, 20-950 Lublin, Poland; e-mail: agnieszka.komor@up.lublin.pl

\section{Magdalena Typa}

Master in Management and Marketing from Warsaw School of Economics (Poland). Currently a PhD. student in Economics also at Warsaw School of Economics. Her scientific interests include: regional economy, economic zones, state aid, business location and operational management.

Correspondence to: Mgr Magdalena Typa; Warsaw School of Economics, Institute of Enterprise; al. Niepodległości 162, 02-513 Warszawa, Poland; e-mail: magdalena.typa@sgh.waw.pl.

\section{Copyright and License}

This article is published under the terms of the Creative Commons Attribution - NonCommercial - NoDerivs (CC BY-NC-ND 3.0) License http://creativecommons.org/licenses/by-nc-nd/3.0/ 